This item was submitted to Loughborough's Research Repository by the author.

Items in Figshare are protected by copyright, with all rights reserved, unless otherwise indicated.

\title{
Ex-rebel authority after civil war: theory and evidence from Côte d'Ivoire
}

PLEASE CITE THE PUBLISHED VERSION

https://doi.org/10.5129/001041521X15923094954447

PUBLISHER

City University of New York

VERSION

AM (Accepted Manuscript)

PUBLISHER STATEMENT

This paper was accepted for publication in the journal Comparative Politics and the definitive published version is available at https://doi.org/10.5129/001041521X15923094954447.

\section{LICENCE}

CC BY-NC-ND 4.0

\section{REPOSITORY RECORD}

Martin, Philip A, Giulia Piccolino, and Jeremy S Speight. 2021. "Ex-rebel Authority After Civil War: Theory and Evidence from Côte D'ivoire”. Loughborough University. https://hdl.handle.net/2134/12639359.v1. 


\title{
Ex-Rebel Authority after Civil War: Theory and Evidence from Côte d'Ivoire
}

Philip A. Martin

Giulia Piccolino

Jeremy S. Speight ${ }^{1}$

This is the accepted manuscript version of an article that has been accepted by the Journal of Comparative Politics.

\begin{abstract}
How do former armed militants exercise local political power after civil wars end? Building on recent advances in the study of "rebel rulers" and local goods provision by armed groups, this article offers a typology of ex-rebel commander authority that emphasizes two dimensions of former militants' power: local-level ties to civilian populations ruled during civil war, and national-level ties to post-conflict state elites. Put together, these dimensions produce four trajectories of ex-rebel authority. These trajectories shape whether and how ex-rebel commanders provide social goods within post-conflict communities and the durability of ex-rebels' local authority over time. We illustrate this typology with qualitative evidence from northern Côte d'Ivoire. The framework yields theoretical insights about local orders after civil war, as well as implications for peacebuilding policies.
\end{abstract}

\section{Word Count}

11,489 including endnotes and acknowledgements 


\section{Keywords}

Civil War; Peacebuilding; Insurgency; Governance; Africa; Côte d'Ivoire

There is a growing recognition that former members of armed movements play important roles in local goods provision and peacebuilding in states recovering from violent internal conflict. When civil wars are ongoing, non-state armed groups and their local-level commanders often become involved in day-to-day affairs in communities under their control, including the provision of security and policing, dispute resolution, and even education and health care. ${ }^{2}$ These "rebel governance" practices fill the vacuum of social order created by civil war. They can also form enduring patterns that persist into peacetime politics. ${ }^{3}$ In many post-conflict states, former combatant leaders play prominent roles not only as members of unified armed forces, but also as non-military bureaucratic appointees, elected politicians, economic entrepreneurs and informal local strongmen. ${ }^{4}$

Yet the nature of former armed group members' local authority can vary dramatically. For example, since the end of the armed conflict in Côte d'Ivoire (2002-2011), former commanders of the Forces Nouvelles (FN) rebel group have played diverse roles in local affairs. Some of these individuals exercise political clout in a formal capacity as elected officials, members of the Ivorian armed forces, or as civil servants of the post-conflict state. In approximately one in five sub-prefectures controlled by the rebel group during the civil war, a former FN member now holds an elected position. ${ }^{5}$ In other areas, former FN commanders exercise power through informal channels based primarily on ties to networks of former rankand-file combatants, as well as ongoing relationships with community leaders. In yet other cases, once-powerful rebel commanders have withdrawn from local politics altogether. 
These differences in the local authority of former armed group leaders are fundamental to understanding peacebuilding and political order in war-torn societies. Yet existing research offers limited insight into this highly varied phenomenon. Where ex-rebels participate in postconflict politics, scholars often treat these actors either as powerful Leviathans who take command of state institutions in order to bend them to their will, ${ }^{6}$ or as entrenched "warlords" who continue their own self-enrichment at the expense of ordinary citizens. ${ }^{7}$ These categorizations mask a more nuanced set of trajectories that define former militants' social and political positions, their roles in local goods provision, and their relationships vis-à-vis the postconflict state. Former commanders and local insurgent organizers sometimes fade out of the political arena entirely, or continue providing social goods informally outside of the institutional channels of the state. In other cases, warlords and militia leaders are promoted to high-level government offices, but lose influence over events on the ground. In short, just as the onset of civil wars can create new and complex constellations of political order, so too does the transition to peace bring remarkably varied transformations to the local authority of non-state armed group members.

This article provides a new conceptual typology to describe and theorize patterns of exrebel authority. By "ex-rebels" we refer specifically to individuals who comprised the mid-level organizational leadership of non-state armed groups. These are the members who are directly involved in wartime operations as field commanders, commissars, or local political bosses. We disentangle two distinct dimensions of these ex-rebels' power: (1) local-level ties developed with populations within their areas of wartime rule, and (2) national-level ties formed with capitalbased elites. Put together, these dimensions produce four distinct trajectories: predation, benevolent warlordism, state capture, and rebels-into-statesmen. Our typology is simple but 
powerful, summarizing how these different dimensions interact to shape how former local militant leaders participate in goods provision, as well as the ability of these actors to withstand political challenges over time. The article illustrates the typology using examples from the warto-peace transition in Côte d'Ivoire, where rebel field commanders and political commissars varied greatly in their post-conflict trajectories. We also show that our typology applies more broadly, capturing patterns of ex-rebel authority in other protracted conflicts where non-state armed groups controlled territory and retained local influence beyond the official termination of violence. $^{8}$

This conceptual brush-clearing exercise is a necessary step towards more nuanced theorizing about post-conflict peacebuilding and statebuilding. Former non-state armed groups play a pivotal role determining how social order is produced, how public goods are provided, and the likelihood for violent remobilization in war-torn societies. ${ }^{9}$ By thinking about ex-rebel authority as a multi-dimensional variable, our typology helps analysts conceptually map out the complex transformations to local politics that occur when armed groups demobilize or assimilate their personnel into the state. Importantly, our framework distinguishes between patterns of authority that are likely to hinder statebuilding and peacebuilding, versus scenarios where former rebels can contribute to the welfare of their societies.

Understanding differences in the quality of ex-rebel authority also has important policy implications. International interveners must confront and navigate the local influence of former mid-level rebel actors when dealing with a variety of policy problems, such as controlling flows of illicit goods and persons, responding to humanitarian crises, or attempting to bolster the capacity of partner governments. ${ }^{10}$ Even when ex-rebel commanders submit to disarmament and state integration, this need not entail the dismantlement of their informal wartime networks. ${ }^{11}$ It 
matters whether the authority of these ex-rebels is based primarily on their local wartime credentials or on their ties to national-level elites, since the effectiveness and consequences of efforts to co-opt or dislodge these actors may be very different in these scenarios.

The rest of the article is organized as follows. After reviewing the existing literature and describing our theoretical typology, we illustrate each category of ex-rebel authority with evidence based on field research in northern Côte d'Ivoire. We also demonstrate the generalizability of our typology by drawing on secondary cases. In the final section, we outline fruitful lines of research generated by our analysis.

\section{Studying the Post-conflict Politics of Rebel Authority}

In the last decade a growing wave of literature has emerged on two previously understudied dimensions of civil wars. First, an important research agenda now exists around the provision of governance by non-state armed actors. ${ }^{12}$ This literature highlights that, in addition to conventional military capabilities, insurgent groups often develop administrative institutions and service delivery mechanisms within territorially based "anti-states" that facilitate social control over civilian populations. ${ }^{13}$ Second, scholars are paying more attention to the roles of former belligerents as participants in local peacebuilding. ${ }^{14}$ For instance, ex-rebels and former militia group leaders can facilitate state authority in peripheral areas by brokering connections and exchanges of resources and information with central political elites. ${ }^{15}$ Former rebels can also "reinvent themselves" as agents of political parties or non-government organizations that are involved primarily in civilian affairs. ${ }^{16}$

These research streams shed light on how wartime political orders emerge, how populations access basic services in conflict zones, and how armed movements participate in 
formal politics or return to violence after civil wars end. Despite these advances, however, we lack an analytical framework that connects the emergence of different wartime orders under nonstate armed groups to the post-conflict authority of middle-tier ex-rebel actors, and that accounts for the highly varied nature of these individuals' local political power. This lacuna reflects two features of the existing literature.

First, there is a strong prescriptive focus in much of the literature, with many studies equating the local authority of ex-rebel commanders with criminality and state failure. ${ }^{17}$ For example, scholars warn against predatory "warlords" who maintain their power through "their ability to manipulate the dangling bureaucratic structures of weak states." ${ }^{18}$ Anders Themnér recognizes this tendency in the peacebuilding literature more broadly, noting that "to the extent that the agency of individual military leaders is acknowledged, scholars commonly frame it in negative terms, where the goal of peacemaking should be to find ways to channel political power through parties rather than individuals, and through civilian leaders rather than the military." ${ }^{19}$ In contrast, other analysts adopt a normative stance in favor of "hybrid" forms of post-conflict governance that incorporate ex-rebels as peacebuilding partners. ${ }^{20}$ Kate Meagher, for instance, notes that research focusing on hybrid forms of post-conflict governance has tended to "celebrate" these arrangements "as a vehicle of embedded forms of order and authority." 21

In other words, whereas scholars of warlordism often cast ex-rebel leaders as incorrigible peace spoilers, critics of externally-imposed liberal peacebuilding characterize the authority of former commanders as a positive reflection of "local ownership" in the reconstruction process. We argue that both perspectives are partially correct, but remain theoretically underspecified. The influence of former armed actors can be predatory and extractive, but also locally embedded and welfare-enhancing. 
A second limitation is that much past research aims to understand the effects of former rebels' political authority for other outcomes — such as the renewal of political violence, ${ }^{22}$ party building, ${ }^{23}$ or democratization ${ }^{24}$ — rather than to investigate the endurance or decline of that authority itself. Although there are empirical studies of cases where former rebel organizations withdrew from formal politics, such as the RUF in Sierra Leone, ${ }^{25}$ these studies rarely identify the conditions under which specific ex-rebel commanders withdraw (or are pushed out) from local political positions.

The most promising work, in our view, has conceptualized local political orders in conflict-torn states in terms of the varied resources and strategies - military, economic, and political - employed by states and non-state challengers. Paul Staniland, for instance, theorizes wartime political orders according to patterns of territorial control and cooperation between states and armed groups. ${ }^{26}$ Romain Malejacq adopts a similar approach to conceptualize forms of political order in failed states, emphasizing the relative internal and external resources available to warlords and states. ${ }^{27}$ However, as with other studies, Malejacq's framework remains limited by the way he conceptualizes warlords' resources along a single dimension that lumps together local and external/national-level sources of political power. ${ }^{28}$ We argue for the analytical utility of disaggregating these dimensions in order to better understand the varied quality and durability of ex-rebel authority.

Overall, the existing literature usefully sheds light on the varied roles and behaviors of ex-rebel actors, and identifies a number of problems these individuals can create for peacebuilding efforts. What is missing, however, is an analytical framework capturing how and why local ex-rebel commanders' authority is preserved, transformed, or swept aside after war's end. Such an approach recognizes that these actors are not desirable or undesirable per se. 
Rather, their roles in post-conflict reconstruction depend on the nature of their local authority. Former mid-tier rebel leaders are capable of creating or disrupting local social orders, and can either aid or hinder post-conflict reconstruction efforts guided by central governments and external interveners.

\section{A Typology of Ex-Rebel Authority}

We offer a "conceptual typology" 29 describing the nature of mid-level ex-rebel authority in postconflict societies. The dimensions of our typology reflect two distinct sources of authority for former militant group commanders: local-level ties established with community residents, and national-level relationships with capital-based elites such as presidents or party leaders. Together these sources of authority impact whether and how ex-rebels provide local goods and sustain their power over time.

In focusing on the "middle managers" of militant groups who are on the front lines of territorial governance, our analytical framework draws on previous studies of command-level actors in non-state armed groups. ${ }^{30}$ Most directly, we build on Themnér's work on ex-mid-level commanders (ex-MiLCs). ${ }^{31}$ Like Themnér, we conceptualize mid-ranking ex-rebels as critical "brokers" who mediate resources and information up and down the political hierarchy in postconflict states. While Themnér focuses on the decision of commanders to remobilize armed networks, our typology captures a broader range of social and political roles for these actors. Specifically, we incorporate insights from anthropological studies in West Africa and elsewhere that conceptualize armed group commanders as types of local "patrons" who can be highly embedded in the communities they control. ${ }^{32} \mathrm{We}$ assume that, while these individuals may have 
diverse ideological agendas, mid-level former rebels seek to preserve and expand their local authority in the postwar period subject to the constraints of their political resources. ${ }^{33}$

\section{Local-level Ties}

Armed movements that aim to govern territory for a prolonged period of time require some level of support from civilian populations to ensure their success. In almost all civil wars, insurgents rely heavily on relationships with non-combatant populations for political support, the provision of material resources, and information regarding the activities of their military opponents. ${ }^{34}$ As individuals with decision-making power over rank-and-file fighters and resources that can be directed towards civilian welfare, mid-level commanders and political organizers are key nodes for the local-level ties that armed movements develop. After transitions to peace, ex-rebels often seek to sustain these local support networks in order to pursue their interests, for example to mobilize electoral support or to remobilize armed supporters. ${ }^{35}$ The strength of local-level ties that link ex-rebel commanders to civilian populations is therefore a crucial feature of the postconflict political environment.

We conceive of "strong" local-level ties as the persistent social bonds that exist between mid-level ex-rebels and local populations after civil war, which are grounded in popular perceptions of legitimacy. By "legitimacy" we refer to the subjective view of a population regarding the appropriateness of sets of rules, institutions, or authority claims advanced by political actors and whether they should be obeyed. ${ }^{36}$ While violent coercion and monetary payoffs may be used, such ties go beyond "compliance as a function of raw power." ${ }^{37}$ While coercion and authority can be difficult to distinguish in practice, strong local-level ties for exrebels can be identified with several indicators: 1) commanders require a low degree of 
monitoring to maintain civilian obedience, 2) civilian support is offered on a voluntary or spontaneous basis (e.g. expressing endorsement), and 3) civilian support is widespread across different social strata. ${ }^{38}$ Measuring these local-level ties requires detailed knowledge of militants' interactions with civilian populations and the rationales underpinning civilian support.

Strong local-level ties influence the exercise of ex-rebel authority after the transition to peace in two primary ways. First, the presence of strong local-level ties that intertwine local rebel leaders with community elites and residents is likely to increase the durability of ex-rebels' authority. As state institutions are re-deployed across the national territory, the original wartime justifications for the presence of armed actors become more tenuous. Ex-rebel commanders may no longer monopolize violence and patronage in communities formerly under their control. In this situation, armed actors that can draw on a bottom-up reservoir of political capital will be better positioned to entrench their position and weather the post-conflict transition. Former militant leaders can find allies among community members in different positions, such as customary authorities, civil society organizations, trade unions, and religious leaders. ${ }^{39} \mathrm{By}$ sustaining thick ties with these actors, ex-rebels have a firmer social base to stand on.

Second, strong local-level ties can generate pressure on ex-rebels to exercise their authority in socially beneficial ways. Scholars have argued, for example, that when citizens and governance actors develop norms of reciprocity and occupy overlapping social spaces, it helps citizens monitor and sanction these public goods providers, encouraging cooperation and accountability. ${ }^{40}$ During transitions from war to peace, the local support and perceived legitimacy of former armed group commanders can similarly influence how these individuals exercise informal power as "co-producers" 41 of public goods. Enduring local-level ties provide a potential channel for civilians to make demands upon ex-rebels during peacetime, and to make 
their continued acceptance of ex-rebel commanders' presence and influence contingent on satisfactory governance performance.

What determines whether the local-level ties of ex-rebel commanders and commissars will be strong or weak? To a large extent, the existence of strong linkages embedding ex-rebels within local communities are a function of the capacities and strategies pursued by armed movements during the conflict period. In terms of concrete actions, armed actors can build relations with civilians through the provision of public goods and services such as security, education, health care and dispute resolution. ${ }^{42}$ Armed groups and their local commanders can also garner legitimacy using rhetorical appeals rooted in ideological worldviews, local belief systems, or identity-based grievances against exclusionary governments. Such practices can persuade local populations that the authority claims of armed actors are rightful and deserve to be respected.

By contrast, where armed movements behave in a more opportunistic and predatory fashion during war, individuals associated with these movements are less likely to enjoy enduring local-level ties. Resource constraints, strategic conditions of the conflict, or corrupt leadership may limit opportunities for armed groups to provide goods and services, requiring local commanders to impel obedience through the threat of violence. ${ }^{43}$ Alternatively, armed movement organizers may obtain support by providing selective material benefits such as rentseeking opportunities for fighters or distributing patronage to community elites. ${ }^{44}$ These mechanisms of control may succeed in wartime. But they ultimately provide a more fragile basis for ex-rebel leaders' local ties in the post-conflict period, since they are contingent on the ability to maintain a local monopoly on coercion and private patronage. 
In sum, the creation of bonds of support and popular legitimacy that intertwine armed actors with local communities can help former rebels to sustain their power after the end of the conflict, and steer that power towards socially productive ends. Several caveats to this discussion are in order. First, the wartime practices of armed groups are rarely uniform across time and space. For example, despite its reputation for ruthlessness, the Resistência Nacional Moçambicana (RENAMO) and their local commanders enjoyed a degree of popular legitimacy in stronghold areas in central Mozambique. ${ }^{45}$ Thus, identifying and measuring local-level ties among ex-rebels requires careful attention to conflict processes on the ground. Second, the link between armed actors' behaviors during war and their popular legitimacy after transitions to peace is powerful but not deterministic. Over time, new opportunities to forge local support may arise for previously unpopular ex-rebels who are well-positioned to deliver the dividends of peace. This brings us to the second key factor shaping the durability of ex-rebel authority: the ability of local ex-rebel leaders to derive political support from relationships to the post-conflict state.

\section{National-level Ties}

The second dimension of our typology is the strength or weakness or ex-rebels' ties to nationallevel elites. Elite-level social networks play important roles in post-conflict states, which are often characterized by weak formal institutions, intense political competition, and swiftly changing alliances among former belligerents. Amid this fluid political terrain, the success or failure of local ex-rebel bosses to develop and sustain relationships with allies based in national capitals will also impinge on their ability to exert influence. Unlike rank-and-file fighters, midlevel commanders and organizers are well-positioned to develop ties with capital-based power 
holders. These individuals often come from the same pre-conflict social milieux as their nationallevel counterparts, and control access to networks of subordinates that can be leveraged to strike up alliances with state elites. ${ }^{46}$ In practice, national-level ties can be measured in terms of formal support from capital-based leaders (e.g. appointments or endorsements), as well as access to patronage controlled by the state.

Relationships with national-level elites are meaningful in two main ways. First, they grant former armed group commanders privileged access to material resources. Central governments in post-conflict states, usually in partnership with international allies and peacebuilding agencies, often channel state resources through armed brokers in the periphery as an expedient means of purchasing stability and exerting influence in difficult-to-reach areas. ${ }^{47}$ Though state elites and external peacebuilders may not desire it, ex-rebels can leverage these resources distributed from the center in ways that strengthen their authority locally. For example, development aid and infrastructure spending can be targeted to political supporters to create or enlarge ex-rebels' clientelist networks. State personnel, such as police forces or tax officials, can also be repurposed to serve the interests of ex-rebels, for example by shielding their economic activities from legal scrutiny. ${ }^{48}$ Armed actors formally associated with the state can also gain privileged access to international markets, feeding their illicit resource businesses. ${ }^{49}$

Beyond these material benefits, ties to national-level elites allow local ex-rebel leaders to consolidate their authority by exploiting the discourse and imagery of legal-rational authority. ${ }^{50}$ As Pierre Englebert argues, legal-rational discourses (or "legal command") represent an especially powerful tool for domination in post-colonial states that are first-and-foremost products of de jure recognition by other actors in the international system, rather than a result of internal processes of state-making. ${ }^{51}$ Even in extreme cases of institutional atrophy, such as in 
the Democratic Republic of the Congo (DRC) or northern Mali, peripheral governance actors often rely on legal command to "order people around," mobilize resources, and buttress their authority at regional and local levels. ${ }^{52}$ Affiliation with formal state institutions can also make governance actors appear more autonomous and independent of private interests. ${ }^{53}$ Individuals who can claim to represent "the state," therefore, will possess significant advantages over competitors.

As states transition from civil war to peacetime politics, ex-rebels and other wielders of local authority participate in intense re-negotiations over access to the benefits associated with sovereign statehood. ${ }^{54}$ Ex-rebel commanders who are successful in establishing national-level alliances can access material and symbolic resources that were previously unattainable, allowing them to expand networks of patronage, direct armed state personnel to their benefit, and employ legal-rational imagery as a tool of domination. Ex-rebels who are disconnected from patrons within the capital-based government, by contrast, may be perceived as being outside the law, and will be more vulnerable to pressures from competing local elites and from international peacebuilders.

\section{Combining the Dimensions: Trajectories of Ex-Rebel Authority}

Figure 1 brings these local- and national-level dimensions together and categorizes the resulting types of authority. We characterize these trajectories in terms of how mid-level ex-rebels continue to provide social goods within local communities, and the likely durability of their authority over time.

In areas where the local support base of ex-rebels is weak, and the authority of former armed actors is not buttressed by vertical ties to the post-conflict state (upper-left quadrant), ex- 
rebels' local authority is characterized by predation. Without a reservoir of political capital among citizens or strong relationships with local community leaders, ex-rebels are unconstrained by a pre-existing social contract with local civilians. To the extent that ex-rebel bosses in these areas continue to exert authority, they are likely to direct their effort primarily towards extorting local populations rather than providing public goods. At the same time, without formal recognition of their position, ex-rebel actors can no longer "mask" their activities behind the veneer of quasi-statehood. This combination of weak local support and a lack of vertical linkages produces an unstable form of authority centered on clandestine forms of extraction and coercion. This situation describes the position of former militia group leaders in several peripheral areas of Côte d'Ivoire, the Democratic Republic of Congo and Colombia. Predatory forms of ex-rebel authority are ultimately brittle. They are unlikely to endure in the face of determined efforts by local populations to push ex-rebels out, or efforts by central governments to restore a monopoly on goods provision.

[Figure 1 here]

In the benevolent warlordism scenario (upper-right quadrant), ex-rebel commanders benefit from strong local-level ties but lack the resources and formal recognition of their authority that come from alliances with national-level actors. Control over core public goods (such as security) remains concentrated in the hands of former rebel actors, but this authority is exercised primarily through informal channels. A strong social contract between ex-rebels and local populations allows former commanders to draw on community resources and supporters, and they may even invest in local development. Armed power-brokers in parts of Somalia, 
Afghanistan, and Liberia are examples of this category. In some cases, ex-rebels in situations of benevolent warlordism possess pro-forma connections to the state (for example through military commissions), but they exercise their authority well beyond their formal job descriptions. This form of ex-rebel authority often exists in parallel with new state institutions, presenting a complementary — and potentially rivalrous — source of governing authority. The authority of ex-rebels under benevolent warlordism is more resilient than in situations of predation, but can still be challenged from above if state elites decide to revoke their tacit acceptance of ex-rebels' local power.

State capture occurs where armed groups fail to cultivate local bases of support during civil war, but where the authority of ex-rebel commanders is elevated through national-level ties to the post-conflict state (bottom-left quadrant). Former militant leaders may be nominated as candidates for ruling political parties, or appointed to bureaucratic or security sector positions that give them formal governing powers. Ex-rebels in the state capture scenario lack popular constraints on their authority and can use their affiliation with the state to shield their participation in illicit economies and other criminal behavior. In some instances of state capture, ex-militants' new linkages to the state facilitate the de-territorialization of their local power base. Without perceived legitimacy among the population, these ex-rebels may "retreat to the barracks" (or the prefectoral office) and withdraw from pockets of territory that are difficult to govern. As such, former militants may have quite limited influence over local security and goods provisions. This is the case with many ex-rebel commanders in postwar Côte d'Ivoire, whose authority is now seen as distant and "corrupted" in the eyes of local populations. Although the state capture type of authority can endure in the short-term, the absence of local popular backing also makes ex-rebels vulnerable to potential challenge by other politicians capable of mobilizing 
broad-based support. Recognition of authority can also be withdrawn by national-level elites if ex-rebels are unable to advance the interests of their capital-based allies or function as loyal political brokers.

In the final category of rebels-into-statesmen (bottom-right quadrant), local ex-rebel leaders combine strong local support with the material and ideational advantages derived from alliances with state elites. This configuration of authority promotes the most far-reaching institutionalization of ex-rebel power. Former militants are likely to remain involved in a broad range of goods provision, and can draw on myriad resources to operate effectively inside the formal political arena and ward off challengers. This trajectory describes the war-to-peace transformations of well-entrenched ex-rebel commanders and commissars in several areas of Côte d'Ivoire, Zimbabwe, and Uganda.

Given the tendency of these theoretical types to cluster together across space, we conceptualize these trajectories at the sub-national level - i.e. across villages, towns, and localities. Of course, these ideal types are intended as conceptual heuristics and need not be mutually exclusive. In reality, within any specific locality there may be elements of different categories mixed together.

\section{Illustrating the Typology: Ex-Rebel Authority in Côte d'Ivoire}

Studying the war-to-peace transition in Côte d'Ivoire provides a unique opportunity to trace the trajectories of ex-rebel authority described by our theoretical typology. Several aspects of the Ivorian case provide analytical leverage. First, the decentralized nature of the Forces Nouvelles (FN) rebellion allows us to isolate local-level patterns within the broader case. From 2002 to 2011 the FN occupied the northern half of the country, while the government of Laurent Gbagbo 
retained administrative control over the south. In rebel territory, the FN developed a complex governance structure that coordinated rebel activity, mobilized resources, and worked with local communities to provide public goods such as security, education and dispute resolution. ${ }^{55}$ Rebel forces divided their territory into ten administrative com'zones, and zone and sector commanders - along with FN civilian delegates - enjoyed substantial autonomy. The decentralized character of the FN occupation led to significant variations in the quality of FN governance and the relationships formed between local FN leaders and occupied populations.

Second, post-conflict peacebuilding in Côte d'Ivoire produced wide-ranging constellations of local order that incorporate former militants in highly varied ways. Many former FN commanders remained locally influential after the fall of Gbagbo's government following the 2010-2011 electoral crisis, despite efforts by the government of Alassane Ouattara to dismantle the FN wartime structure. ${ }^{56}$ Other ex-FN members faded from the public spotlight, or shifted into formal government positions that altered the resources available to them. Leveraging these sources of variation within a single case allows us to parse out the role of exrebels' local- and national-level ties for their postwar trajectories of authority, while holding constant factors such as group ideology.

Our analysis draws on extensive field research, including over one hundred interviews with politicians, bureaucrats, former rebel group members, community leaders and citizens. These interviews were conducted over a three-month period from June to August 2017 across dozens of sous-préfectures (the smallest administrative unit in Côte d'Ivoire) in former rebelheld areas, and in different neighborhoods of Bouaké and Korhogo, the two largest cities occupied by the rebellion. ${ }^{57}$ We selected research sites on the basis of a convenience sample of sous-préfectures, with an aim towards gathering evidence from diverse socioeconomic and 
ethnolinguistic regions in rebel-held territory, as well as urban and rural areas. In each locality, we conducted at least one structured interview with a community leader - for instance a village chief or civil society leader - using a standardized questionnaire that included factual questions about the rebel occupation and the post-conflict political roles of former FN leaders in the community. ${ }^{58}$ This data was triangulated with additional, semi-structured interviews with citizens, government officials, and former rebel members either in the sous-préfecture or the regional capital, using snowball-sampling. ${ }^{59}$

Predation. Where local-level support for ex-rebel leaders is weak, and ties to national-level political networks are absent, the resulting outcome is predation. The sub-prefecture of Kpata in western Côte d'Ivoire illustrates the predation category. Located in the rugged mountains northeast of the city of Man in the Tonkpi region, Kpata fell under the control of the zone commander Losseni Fofana during the rebellion. Unlike in the zone capital of Man, however, the local Forces Nouvelles chef de poste in Kpata (known to residents as "Bava") showed little concern for the well-being of the population. Several episodes of violent repression against the population occurred in the early months of the FN occupation, and civilians spoke of the frequent mistreatment of community members, including elders and women, at the hands of FN forces. ${ }^{60}$ Kpata was one of the few localities we visited where a local youth militia, and not the FN commander, took on the primary role of providing security and policing during the rebel occupation. ${ }^{61}$

After the post-conflict transition, few FN members in Kpata integrated into the national army or other state positions. The chef de poste found himself cut adrift from national leaders, and continued to organize his subordinates to operate informal road checkpoints in the area to 
levy taxes, especially during the first two years of the post-conflict transition. ${ }^{62}$ However, Bava and his fighters were no longer attached to a larger organizational superstructure that justified their extraction. The ex-commander's predatory behavior placed him and his fighters in a precarious position vis-a-vis the population, and over time community leaders began to call on the re-deployed police and gendarmerie forces to intervene. One village elder explained, "Here the rebels continued to run their barrages on the roads, they had nothing else to do ... We have no police station here, so it is still hard. But they are not so powerful anymore." ${ }^{\prime 63}$

A similar trajectory occurred for local ex-rebel leaders in the region of Worodougou and its capital Séguéla. In this region, the majority of the Malinké population initially shared the political goals of the rebellion and many local inhabitants enrolled in the FN. The Worodougou region is peripheral and poor, but its gold and diamond mining sites were a major source of revenue for the FN. Rebel commanders and political delegates in this area, such as Issiaka Ouattara and Mamadou Bakayoko, respected the authority of local Rassemblement des républicains (RDR) politicians and Malinké chiefs, and had difficulty challenging their position of power. ${ }^{64}$ As a result, the scope of FN governance remained narrow.

The influence of former FN leaders in Séguéla diminished rapidly after the end of the civil war in 2011. Senior former commanders who reintegrated into the army involved themselves primarily in the illegal exploitation of natural resources, activities which took place in remote areas far from the paved road. However, local authorities (particularly the re-deployed prefectoral corps) did not approve of these illegal actions and were effective at curbing them, particularly in the case of diamond mining. ${ }^{65}$ Interviewees in the region stress that today, former rebel leaders seem to have lost interest in Séguéla. As one local administrator said, "there are a few former soldiers of commander Wattao [Issiaka Ouattara] who are still there, but they are not 
many. After the election, the FN wanted to be close to Abidjan, the centre of political power, in order to have their share of the cake ... here they came to enrich themselves and leave." ${ }^{66}$ Demobilized combatants in Séguéla expressed similar frustration that their commanders seem to have lost any interest in them. ${ }^{67}$

Two related dynamics appear to have curtailed ex-rebel authority in Séguéla. First, the FN's limited success in providing social goods during the occupation weakened the popularity of former rebel commanders in the area. Local officials explained that many residents remembered FN governance as a period of arbitrary rule and sometimes brutal violence, and few politicians wanted to sustain an alliance with former FN commanders. ${ }^{68}$ Second, the re-establishment of RDR party hegemony in the region "crowded out" the ability of politically ambitious FN leaders to formalize their local positions in the post-conflict state. ${ }^{69}$

The predation trajectory can be found in other post-conflict states. In Colombia, for example, local leaders of paramilitary groups experienced similar difficulties sustaining authority following the process of demobilization. In 1999, the Bloque Catatumbo (BC), a faction of the Autodefensas Unidas de Colombia (AUC), occupied the municipality of Tibú in the department of Norte del Santander. BC commanders relied largely on violence and intimidation to enforce control, ${ }^{70}$ and did little to consolidate a strong social base among the population. ${ }^{71}$ The $\mathrm{BC}$ retained control of the Tibú municipality until their demobilization in $2004,{ }^{72}$ but their power remained predicated on violence and economic extortion. ${ }^{73}$ Because the group did not build legitimacy during the armed conflict, ex-paramilitary commanders lacked strong social ties or support among the local population. Vertical ties between BC field commanders and Colombian political elites, meanwhile, which constituted a major source of support for paramilitaries, grew weaker when the Colombian government withdrew its support to the AUC and curbed legal 
impunity for paramilitaries. Over time, the authority of local BC leaders receded and their units disintegrated. In the words of one former combatant, "all of my compañeros went their own ways. Nothing remained." 74

Benevolent Warlordism. In cases where ex-rebels enjoy strong ties to local communities but lack support from national-level leaders, the outcome is benevolent warlordism. This category characterizes several regions in Côte d'Ivoire where FN rebels developed sophisticated governance systems and collaborated with local elites. Although some former FN commanders in these areas were affiliated with the state via their positions in the national army, their local influence is largely unrelated to their official duties.

In Katiola, the capital of the Hambol region, the former zone commander Herve Touré ("Vetcho") remains a powerful figure in local governance. At the outbreak of the rebellion in 2002, Vetcho became the sector commander in the nearby department of Dabakala before being promoted to zone commander in Katiola in $2004 .{ }^{75}$ Vetcho's appointment brought a considerable improvement in the relations between the FN and the local population in Katiola, which were strained under the previous commander. ${ }^{76}$ Vetcho's efforts to restore basic services in the city, combined with the fact that Vetcho was a "son of the land" — born and raised in Katiola — helped to restore the confidence of the population in the FN's political project. According to a traditional chief in Katiola, "we had a lot of discussions with him, he explained us his political mission. He said that everyone could call him if there were problems. He was always very approachable." ${ }^{" 77}$ Youth from the local ethnic group, the Tagbana, started joining the FN in significant numbers only after Vetcho's arrival. ${ }^{78}$ 
Although Vetcho left Katiola after the end of the rebellion in order to rejoin the Agence nationale de stratégie et d'intelligence (ANSI), and was later promoted in 2014 to be the commander of the third infantry battalion of the Ivorian army stationed in Bouake, his informal ties to the community in Katiola remained strong. Vetcho continues to visit Katiola periodically in a private capacity. During these visits, he meets with traditional authorities and attends social ceremonies. He is also known to provide financial assistance to his former fighters, and "bring help to the population." ${ }^{79}$ Community leaders and local government officials in Katiola also solicit Vetcho to address problems of criminality and disorder among former FN elements living in the region..$^{80}$

However, strained relations with the central government threaten the local authority of ex-FN members like Vetcho. State authorities tolerate Vetcho's influence in Katiola insofar as he can help the Ouattara regime to keep former combatants in the region under control, an issue that has taken on increased urgency in the wake of several army mutinies and ex-combatant protests in 2014 and $2017 .{ }^{81}$ But Vetcho could always be relocated outside the region in the future if the Ouattara government decided that his informal authority represents a threat to the state. Recent events in the city of Korhogo illustrate this possibility. The powerful ex-zone commander Fofié Kouakou Martin exercised considerable influence in Korhogo after 2011, in part due to his record of effective service provision during the civil war. Yet by 2016 Fofié's authority prompted the Ouattara government to re-position Fofié to Daloa in the Haut Sassandra region in order to weaken his ties to armed supporters. ${ }^{82}$

In neighboring Liberia, some armed group commanders followed a similar pathway of benevolent warlordism after the conclusion of the country's second civil war in 2003. On the Guthrie rubber plantation, militants organized by a former Liberians United for Reconciliation 
and Democracy (LURD) major, Sumo Dennis, took a number of steps to build local legitimacy, including developing a sophisticated organizational structure for managing the activities of rubber tappers and mediating disputes within the communities they controlled ${ }^{83}$ However, the fact that the Liberian state did not codify the authority of former LURD commanders jeopardized the political position of these ex-rebels over time. Ellen Johnson Sirleaf, elected in 2006, made the repossession of Guthrie and other "irregular" rubber plantations in Liberia a top priority. ${ }^{84}$ Although former LURD commanders retained significant local power in Guthrie after the postconflict transition, the absence of strong national-level ties to members of the post-conflict state ultimately left them vulnerable to displacement.

State Capture. State capture occurs where militants' local ties to the population are weak, but commanders bolster their authority through vertical ties to the post-conflict state. We observed state capture in several localities in post-conflict Côte d'Ivoire. In the central region of Gbeké and in northeastern Bounkani, for example, local populations viewed the presence of the rebels as an abusive occupation, rather than a liberating force. In Gbeké, most of the population is Baoulé, a group that historically supported the old ruling party, the Parti Démocratique de la Côte d'Ivoire (PDCI). From the start, many Baoulé in Gbeké showed scant enthusiasm for what they perceived as a "northern" rebellion. Although they had no particular sympathy for president Laurent Gbagbo either, relatively few Baoulé joined the FN, and the relationship between the local population and the FN was strained during the occupation. ${ }^{85}$ In the department of Béoumi, for example, violence against civilians by FN elements was common despite the efforts of the local FN commander to discipline his troops and prevent abuses. ${ }^{86}$ 
In the aftermath of the war in 2011, some former FN commanders and civilian leaders in the Gbeké region accepted positions within the military, police and gendarmes, or took up elected positions. Others left to take up appointments elsewhere. Among commanders who remained in the area, their activities were limited to their official duties in the security forces, such as military training exercises and police patrols. Community leaders and citizens in the villages of Béoumi, Sakassou and Djébonoua described very limited interactions with former FN leaders, who no longer visited these smaller localities or figured prominently in local politics. ${ }^{87}$ In the village of Botro, a civil society leader explained that "since the reunification, the rebel com-secteur now works as the gendarmerie commandant. His men don't terrorize us anymore, really we do not see him much at all." $\$ 8$

Post-conflict order in the northeastern region of Bounkani illustrates another variant of state capture. As in Gbéké, pre-conflict political alignments in Bounkani and poor wartime governance performance hindered the ability of the FN to legitimize its authority. The relationship between Bounkani's Lobi population and the FN was fraught with tension. Many Lobi felt that FN rule, particularly the system of taxation installed by the rebel commanders, unfairly targeted Lobi leaders, traders and farmers. ${ }^{89}$

Since the removal of Laurent Gbagbo in 2011, former FN leaders have exercised authority in this region through formal appointments by the Ouattara government. After accepting a command position within the Ivorian special forces in Abidjan, the former zone commander stationed in the regional capital of Bouna during the civil war, Morou Ouattara, was reassigned back to Bounkani as the of the head of the battalion responsible for security in the east (BSE). Tuo Fozié, the former director of the police and gendarmerie for the FN, became the Prefect for the Department of Bouna and the administrative Region of Bounkani. And Philippe 
Hien, who played a central role as part of the FN to resolve tensions between the rebels and the Lobi community during the conflict, is the current head of the conseil régional for Bounkani. Finally, the former zone commander in Séguela, Issiaka Ouattara ("Wattao"), remains a political fixture in his hometown of Doropo, where he is implicated in illicit gold mining activities. As the commander of the Republican Guard corps, Issiaka Ouattara can command considerable state resources and shield himself from official scrutiny. ${ }^{90}$

Despite their strong national-level ties and near-monopoly over local state positions, exrebels in Bounkani have struggled to provide political order and limit post-conflict violence. Since the reunification of the country, for example, conflicts over land use have pitted Lobi farmers against the Peul and indigenous Koulango, leading to a set of violent clashes in March 2016 that left more than twenty people dead and displaced thousands to refugee camps in Burkina Faso. ${ }^{91}$ The inability or unwillingness of the local political class, including Morou Ouattara, "Wattao," Fozié, and Philippe to resolve these conflicts over land, coupled with the manipulation of local elections and the ongoing involvement of former rebels in illicit transborder trade, have fed the view among local residents that these ex-rebels have "hijacked" the state to their own benefit and to the detriment of many living in Bounkani. ${ }^{92}$

Several Afghan warlords who led armed factions during the civil wars of the 1990s and who parachuted into regional government offices after 2004 illustrate additional cases of state capture. For instance, Gul Agha Sherzai, the governor of Nangarhar Province from 2005 to 2013, and currently a minister in the Afghan government, owed his appointment as provincial ruler to his strong ties with president Hamid Karzai and with the U.S. military. Sherzai was a co-ethnic Pashtun of the local population but had "no pre-existing base of power in the province and relied on the support of the regime to establish himself as new strongman in town." ${ }^{93}$ Sherzai took 
advantage of opportunities to broker new alliances with local middlemen and accumulate political power, but the governor's sphere of control remained limited. As with other cases of state capture, the authority of these ex-rebels "reflected a negotiated management, not a monopolization, of coercion." ${ }^{94}$

Rebels-into-Statesmen. Rebels-into-statesmen describes cases where ex-rebels buttress their authority with local social bases and national-level linkages. In Côte d'Ivoire, FN members turned rebels-into-statesmen were often local commissars and delegates affiliated with the civilian wing of the rebellion, who leveraged their record of wartime governance to launch careers in electoral politics. ${ }^{95}$ For example, in the region of Poro, whose capital Korhogo was the second largest city controlled by the rebellion, the civilian branch of the FN was able to establish a positive record of local governance. While other civilian branches of the FN existed more on paper than in practice, the Korhogo branch played a significant role since 2002 when it became the cabinet civile. From 2002 to 2011, the local FN administration involved themselves in a broad range of local affairs, from health and education to divorce disputes. They also played a key coordinating role for civil society groups and international organizations such as the UN Operation in Côte d'Ivoire (UNOCI) working in Korhogo. ${ }^{96}$

Popular support "from below" and vertical linkages "from above" interacted and reinforced ex-rebel power in the Poro region. The legitimacy that the FN derived from their relatively effective governance record established an enduring base of local support that helped some of its members to engage in political careers. These members included Kanigui Soro, who was the former delegate general of the FN in Korhogo, and Alphonse Soro. ${ }^{97}$ Both Kanigui and Alphonse were elected to parliament in 2011, representing constituencies in the Poro Region. 
Kanigui and Alphonse also enjoyed strong personal relationships the former FN Secretary General and current President of the National Assembly, Guillaume Soro, from their time as members of the national student union Fédération Estudiantine et Scolaire de Côte d'Ivoire (FESCI). President Alassane Ouattara's party, the RDR, also endorsed former rebel candidates in Poro. These national-level ties allowed ex-rebels like Kanigui and Alphonse to expand their patronage power and associate themselves with the post-conflict state after 2011.

Of course, even rebels-turned-statesmen are not immune from challenges. In Côte d'Ivoire, sustaining support from the ruling Rassemblement des houphouëtistes pour la démocratie et la paix (RHDP) is a central challenge for many ex-FN members. As in the case of Séguéla, the ruling party establishment has sometimes stifled the political ambitions of former FN. As Kanigui Soro explained: "in some localities, the [RDR] politicians have come back after the crisis and they ended up in competition with the FN." ${ }^{98}$ Challenges to the local political authority of ex-rebels in Poro have increased leading up to the 2020 Presidential elections in Côte d'Ivoire, as a result of the growing national-level political rivalry between Ouattara and Guillaume Soro, with whom many mid-level ex-rebels remained politically affiliated. ${ }^{99}$ Nevertheless, ex-FN members with sufficient local legitimacy have proven to be resourceful political actors. Kanigui, for example, managed to be re-elected in 2016 as an independent candidate, after the RHDP disavowed his candidacy. ${ }^{100}$

The rebels-into-statesmen trajectory garners significant attention from scholars in political science. ${ }^{101}$ Across Africa and Asia, ex-rebels associated with armed liberation movements and the "reformist insurgencies" of the 1970s and 1980s that took power through guerrilla warfare are typical cases of this category. ${ }^{102}$ In Zimbabwe, for example, wartime mobilization tactics by the Zimbabwe African National Union (ZANU) - including revolutionary 
meetings (pungwes), and appeals to local religious "spirit mediums" - provided a popular base for ZANU members who transitioned into local politics. In the Dande district, local ZANU Political Commissars adopted many of the community roles previously reserved for village chiefs, such as establishing village committees and enforcing moral codes. ${ }^{103}$ After ZANU guerrillas took power in 1980, many ZANU members gained status at the ward and district level as elected politicians and local party bosses. ${ }^{104}$ To reinforce their authority, ex-ZANU commissars leveraged their connections to the ZANU-PF party-state, which sought to extend the party structure throughout rural areas. ${ }^{105}$ According to Kriger, for example, ZANU party organizers who had previously operated "guerrilla courts" during the liberation war enjoyed the blessing and resources of the central party committee after 1980, and "took it on themselves to punish people who did not obey party rules." ${ }^{106}$ The confluence of local-level ties and strong connections to the central state helps to explain the resiliency of ex-ZANU members' grip on rural politics in much of Zimbabwe over thirty years after the end of the liberation war.

\section{Discussion and Conclusion}

In many post-war societies, middle-ranking ex-rebel members remain influential political actors long after the transition to peace. Few studies, however, have theorized ex-rebel authority in terms of the different political resources available to these actors. By unpacking ex-rebel authority along its local and national-level dimensions, this paper engages in the conceptual work necessary for a more nuanced understanding of how post-conflict political orders are generated and sustained in practice. Sub-national evidence from northern Côte d'Ivoire illustrates the variety of outcomes captured by our typology. Our analysis can also be applied to other cases of 
post-conflict transitions that involve anti-state rebellions, secessionist insurgencies, or other militias that govern territory and operate autonomously from the state. ${ }^{107}$

Although our approach in this article is inductive and concept-oriented rather than theorytesting, our typology invites a research agenda focused on developing more nuanced models of post-conflict peacebuilding. We identify three streams for future work.

First, more research is needed to understand the preservation or decline of militants' local ties to civilians during war-to-peace transitions. Co-ethnic ties and levels of coercive control have received the most attention in the civil wars literature, ${ }^{108}$ yet these factors do not fully explain the endurance of ex-rebels' local-level ties. In the course of our fieldwork, we visited areas where the local support for co-ethnic rebels largely faded away after the end of the conflict, such as in Séguéla. By contrast, in areas such as Man in western Côte d'Ivoire, nordiste FN rebels did not share co-ethnic ties with the local Yacouba population, but local zone and sector commanders nevertheless succeeded in garnering allegiance and perceived legitimacy. ${ }^{109}$ Future research ought to rigorously examine the effects of wartime governance performance and individual rebel commander leadership on the durability of social contracts between rebels and civilians, factors that have received scant attention by political science scholars.

Second, the strategies of postwar state elites - who may choose to empower ex-rebels in some areas but not others - merits further attention. What explains states' strategic choices? Here scholars might examine the role of pre-war social networks among armed group members, as well as processes of wartime socialization. ${ }^{110}$ In the case of Côte d'Ivoire, former FN commanders and civilian delegates with pre-war connections to Guillaume Soro's student union, FESCI, or to President Alassane Ouattara's political circles, were often favored by the postwar regime and promoted to coveted state positions. Wartime cooperation between local commanders 
and national elites aligned with armed factions may also produce enduring bonds that last into the peacetime era, and forge the basis for links between peripheral areas and the capital. Finally, the interaction between ex-rebels' local-level and national-level ties deserves further exploration. For example, ex-rebels with reputations for effective service delivery might be well-positioned to garner national-level ties in the post-conflict period, as capital-based elites seek to align themselves with effective local brokers. ${ }^{111}$

Third, our typology suggests the need for more nuanced theorizing about the implications of ex-militant authority for statebuilding, democratization, and development. Different forms of ex-rebel authority are likely to have different consequences for post-conflict reconstruction. Predation appears to be the most disruptive form of authority, with unconstrained ex-rebel leaders operating largely in the shadows with few mechanisms of accountability. At the same time, predatory ex-rebels can be swept away relatively easily by a post-conflict regime concerned with asserting its power. The rebel-into-statesmen trajectory, by contrast, can produce enduring patterns of authority, with potentially positive implications for stability and statebuilding. However, the rebels-into-statesmen category has equivocal consequences for democracy: powerful ex-rebel actors may employ their considerable resources to steamroll political rivals and restrict electoral competition. ${ }^{112}$ While the creation of governing parties by former rebels can contribute to meaningful political competition, this may be limited to cases where insurgents' takeover of the state is not total. The consequences of highly entrenched exrebel authority for other aspects of local democracy - such as civic engagement and women's political participation - also merit future study.

The consequences of the benevolent warlordism and the state capture scenarios are the most ambiguous and under-researched. On the one hand, socially-embedded military strongmen 
can benefit communities in the short term, helping to establish local order and providing livelihoods to the population. ${ }^{113}$ In this sense, Malejacq is correct when he argues that warlords "may exercise a type of authority that is more durable and flexible" than what central states and international peacebuilders can supply. ${ }^{114}$ However, benevolent warlordism is likely to hinder centralized statebuilding and the uniform consolidation of public authority in the long run, maintaining the post-conflict state in a suboptimal equilibrium of weak authority and potentially unstable hybrid governance. In Côte d'Ivoire, for example, some ex-rebel commanders who remained popular among local populations, such as Fofié Kouakou Martin, emerged as serious threats in the eyes of the Ouattara government. ${ }^{115}$ By contrast, the state capture scenario may be preferable from the perspective of the central regime, even as it leads to the alienation of the local population from a post-conflict state that is perceived as distant and illegitimate. Thus, simply identifying the existence of political authority in the hands of ex-rebels is insufficient for drawing firm distinctions between "strong" and "weak" states. Instead, scholars should explore the potential tradeoffs between co-opting ex-rebel power brokers to achieve national stability, on the one hand, and achieving local order and development, on the other.

Policy-makers who aim to support economic recovery, social cohesion, and state capacity-building after civil wars cannot avoid confronting the local authority of ex-rebel actors. In some cases, this means channeling external resources through these individuals and incorporating them directly into peacebuilding initiatives when they are best-positioned to oversee their implementation, as with demobilization and reintegration programmes. But navigating ex-rebel actors effectively requires a nuanced understanding of how these individuals sustain their authority and to what ends. Former militants who are locally embedded can present a conundrum. These actors can use their local influence and mobilization power (along with 
peacebuilding resources) as bargaining leverage to resist accountability to elected leaders. Subordinating these actors to the state may require more than their pro-forma integration into formal military or civil service positions. Eventually, central governments must successfully supplant the roles of these ex-rebels as guarantors of social order and basic goods provision within their areas of influence. ${ }^{116}$ In cases where ex-rebels exercise authority primarily via their national-level ties, they may not be effective interlocutors for restoring state legitimacy in the eyes of local citizens. External peacebuilders who channel resources through these ex-rebel actors may inadvertently contribute to the erosion of a more meaningful social contract between citizens and the post-conflict state. 


\section{Acknowledgements}

The authors are grateful for comments on previous versions of this article from Olabanji Akinola, Shane Barter, Saskia Brechenmacher, Cullen Nutt, Chris van der Borgh, conference participants at the 2018 International Studies Association Annual Convention in San Francisco, the 2018 Canadian Association and African Studies Annual Conference in Kingston, Ontario, the 2018 Conflict Research Society Conference in Birmingham, UK, as well as two anonymous reviewers. We thank Abel Gbala, Bakary Soro and Amidou Coulibaly for providing research assistance in Côte d'Ivoire, and Anzan Komenan Yaya for help with transcribing interviews. Funding for the research of this project was provided by MIT GOV/LAB, the MIT Center for International Studies and Santander UK.

1. The authors contributed equally to the research and writing of this article.

2. Zachariah Cherian Mampilly, Rebel Rulers: Insurgent Governance and Civilian Life during War (Ithaca and London: Cornell University Press, 2011); Ana M. Arjona, Nestor Kasfir and Zachariah Cherian Mampilly, eds., Rebel Governance in Civil War (Cambridge: Cambridge University Press, 2015); Ana M. Arjona, Rebelocracy: Social Order in the Colombian Civil War (New York: Cambridge University Press, 2016); Meghan Stewart, "Civil War as State Making: Strategic Governance in Civil War,” International Organization 72 (Winter 2018), $205-226$. 3. Sarah Zukerman Daly, Organized Violence after Civil War: The Geography of Recruitment in Latin America (Cambridge: Cambridge University Press, 2016).

4. Mats Utas, ed., African Conflicts and Informal Power: Big Men and Networks (London \& New York: Zed Books, 2012). Nathalie Duclos, ed., War Veterans in Postwar Situations: Chechnya, Serbia, Turkey, Peru, and Côte d'Ivoire (New York: Palgrave Macmillan, 2012).

5. Philip A. Martin, Giulia Piccolino and Jeremy Speight, "Les conséquences d'une gouvernance rebelle: enquête au nord de la Côte d'Ivoire," Bulletin du Centre FrancoPaix, 3 (January 2018), 1-7.

6. Monica Duffy Toft, Securing the Peace: The Durable Settlement of Civil Wars (Princeton: Princeton University Press, 2010); Terrence Lyons, "The importance of winning: Victorious insurgent groups and authoritarian politics," Comparative Politics, 48 (January 2016), 167-84. 
7. William Reno, Warlord Politics and African States (Boulder and London: Lynne Rienner, 1998); Jesse Driscoll, Warlords and Coalition Politics in Post-Soviet States (New York: Cambridge University Press, 2015).

8. We exclude from our analysis cases of highly asymmetric conflicts where non-state armed groups are too weak militarily to challenge their opponents and control territory for extended periods. We also exclude conflicts that end in decisive government victories where former rebels are eliminated or imprisoned.

9. Zukerman Daly; Robert A. Blair and Pablo Kalmanovitz, "On the Rights of Warlords: Legitimate Authority and Basic Protection in War-Torn Societies," American Political Science Review, 110 (August 2016), 428-440.

10. Sharri Plonski and Zahbia Yousuf, Borderlands and Peacebuilding: a View from the Margins (London: Conciliation Resources, 2018).

11. For a related argument see Dipali Mukhopadhyay, "Disguised Warlordism and Combatanthood in Balkh: The Persistence of Informal Power in the Formal Afghan State," Conflict, Security \& Development, 9 (2009), 544. 12. Arjona, Kasfir and Mampilly; Arjona, 2016; Mampilly.

13. Stewart.

14. Volker Boege, M. Anne Brown, and Kevin P. Clements, "Hybrid political orders, not fragile states," Peace Review: A Journal of Social Justice, 21 (February 2009), 13-21; Reyko Huang, The Wartime Origins of Democratization: Civil War, Rebel Governance, and Political Regimes (Cambridge: Cambridge University Press, 2016); Anders Themnér, "Former Military Networks and the Micro-Politics of Violence and Statebuilding in Liberia," Comparative Politics, 47 (April 2015), 334-53; Anders Themnér, ed., Warlord democrats in Africa: exmilitary leaders and electoral politics (London: Zed Books, 2017); Zukerman Daly.

15. Themnér, 2015.

16. Zukerman Daly, p. 2; Carrie Manning and Ian Smith, "Political party formation by armed opposition groups after civil war," Democratization 23 (July 2016), 972-989; Mimmi Söderberg Kovacs and Sophia Hatz, "Rebel-toparty transformations in civil war peace processes 1975-2011," Democratization 23 (July 2016), 990-1008.

17. William Reno, "Understanding Criminality in West African Conflicts," International Peacekeeping, 16 (January 2009), 47-61; Robert I. Rotberg, ed., State Failure and State Weakness in a Time of Terror (Washington, DC: Brookings Institution Press, 2003); Anne L. Clunan and Harold A. Trinkunas, eds., Ungoverned Spaces: Alternatives to State Authority in an Era of Softened Sovereignty (Stanford: Stanford University Press, 2010). 18. Kimberly Marten, Warlords: Strong-arm Brokers in Weak States (Ithaca: Cornell University Press, 2012), 25. 
19. Anders Themnér, "Introduction: Warlord democrats: wartime investments, democratic returns?" in Themnér, $2017,3$.

20. David Roberts, "Hybrid Polities and Indigenous Pluralities: Advanced Lessons in Statebuilding from Cambodia," Journal of Intervention and Statebuilding 2 (February 2008), 63-86; Boege, Brown, and Clements; Clunan and Trinkunas.

21. Kate Meagher, "The Strength of Weak States? Non-State Security Forces and Hybrid Governance in Africa," Development and Change, 43 (September 2012), 1074.

22. Themnér, 2015; Zukerman Daly.

23. John Ishiyama and Michael Widmeier. "Territorial Control, Levels of Violence and the Electoral Performance of Former Rebel Political Parties After Civil Wars," Civil Wars 15 (December 2013), 531-550.

24. Huang; Themnér, 2017.

25. Kieran Mitton, "Where is the War? Explaining the Peace in Sierra Leone," International Peacekeeping, 23 (November 2013), 321-337.

26. Paul Staniland, "States, Insurgents, and Wartime Political Orders," Perspectives on Politics, 10 (June 2012), $243-64$.

27. Romain Malejacq, "Warlords, Intervention, and State Consolidation: A Typology of Political Orders in Weak and Failed States," Security Studies, 25 (February 2016), 85-110.

28. Malejacq acknowledges that both local legitimacy and external resources and alliances are important for warlord authority, but does not consider the theoretical implications of examining these dimensions of power separately.

29. David Collier, Jody LaPorte and Jason Seawright, "Putting Typologies to Work: Concept Formation, Measurement, and Analytic Rigor,” Political Research Quarterly, 65 (March 2012), 217-32.

30. See in particular Marten; Malejacq; Reno, 2009; Utas 2012.

31. Themnér, 2015.

32. Danny Hoffman, "The Meaning of a Militia: Understanding the Civil Defence Forces of Sierra Leone," African Affairs, 106 (2007), 652-654; Brian McQuinn, After the Fall: Libya's Evolving Armed Groups (Geneva: Small Arms Survey, 2012), 16; Utas 2012.

33. This assumption holds in many post-conflict settings, see for instance Utas 2012; Themnér, 2015. In some cases, ex-rebels may decline to seek local authority for idiosyncratic reasons outside the scope of our theory. For example, 
former militants may migrate abroad or pursue professional careers that lead them away from their areas of wartime control. For an analysis of ex-combatants' peacetime incentives at the leadership and rank-and-file level, see Joanna Spear, "Disarmament, Demobilization, Reinsertion and Reintegration in Africa," in Oliver Furley and Roy May, eds., Ending Africa's Wars: Progressing to Peace (London \& New York: Routledge, 2006).

34. Mampilly, pp. 53-55; Ana Arjona, "Civilian Cooperation and Non-Cooperation with Non-State Armed Groups: The Centrality of Obedience and Resistance," Small Wars and Insurgencies, 28 (July 2017), 757.

35. Themnér, 2015; Zukerman Daly.

36. Margaret Levy, Of Rule and Revenue (Berkeley: University of California, 1988); Ian Hurd, "Legitimacy and Authority in International Politics," International Organization, 53 (Spring 1999), 379-408; David A. Lake, "Rightful Rules: Authority, Order and the Foundations of Good Governance," International Studies Quarterly, 54 (September 2010), 587-613.

37. Lake, p. 588.

38. This operationalization draws on Arjona, 2017, 761-62.

39. Mampilly.

40. Robert D. Putnam, Making Democracy Work: Civic Traditions in Modern Italy (Princeton, NJ: Princeton University Press, 1994); Lily Tsai, Accountability without Democracy: Solidarity Groups and Public Goods Provision in Rural China (Cambridge and New York: Cambridge University Press, 2007).

41. Elinor Ostrom, "Crossing the Great Divide: Coproduction, Synergy, and Development," World Development, 24 (June 1996), 1073-1087.

42. Arjona, 2016; Stewart.

43. Arjona, 2017; Stathis Kalyvas, The Logic of Violence in Civil War (Cambridge: Cambridge University Press, 2006).

44. Paul Collier and Anke Hoeffler. "Greed and grievance in civil war." Oxford economic papers, 56 (October 2004), 563-595.

45. Lisa Hultman, "The Power to Hurt in Civil War: The Strategic Aim of RENAMO Violence," Journal of Southern African Studies, 35 (November 2009), 821-834; Nikkie Wiegink, "Former Military Networks a Threat to Peace? The Demobilisation and Remobilization of Renamo in Central Mozambique", Stability: International Journal of Security \& Development, 56 (November 2015), 1-16. 
46. Christopher R. Day, “The Fates of Rebels: Insurgencies in Uganda,” Comparative Politics, 43 (July 2011), 443.

47. Marten, p. 29.

48. Staniland 2012; Pierre Englebert and Denis Tull, "Postconflict Reconstruction in Africa: Flawed Ideas About Failed States,” International Security, 32 (Spring 2008), 106-139.

49. Reno, 1998.

50. Max Weber, "Politics as a Vocation," in H.H. Garth and C.W. Mills, eds., Essays in Sociology (New York: Macmillian, 1946), 26-45.

51. Pierre Englebert, Africa: Unity, Sovereignty \& Sorrow (Boulder and London: Lynne Rienner Publishers, 2009).

See also John L. Comaroff and Jean Comaroff, "Law and Disorder in the Postcolony," in John L. Comaroff and Jean Comaroff, eds., Law and Disorder in the Postcolony (Chicago: University of Chicago Press, 2006), 1-56.

52. Englebert, pp. 5-7.

53. Timothy Mitchell, "The Limits of the State: Beyond Statist Approaches and their Critics," American Political Science Review, 85 (March 1991), 77-96.

54. Denis M. Tull, "Troubled state building in the DR-Congo: the challenge from the margins," The Journal of Modern African Studies, 48 (December 2010), 643-661; Tobias Hagmann and Didier Péclard, "Negotiating Statehood: Dynamics of Power and Domination in Africa," Development and Change, 41(July 2010), 539-62. 55. Moussa Fofana, "Des Forces nouvelles aux Forces républicaines de Côte d'Ivoire," Politique africaine, 122 (November 2012), 161-178; Jeremy Speight, "Rebel Organisation and Local Politics: Evidence from Bouna (Northern Côte d'Ivoire, 2002-10)," Civil Wars, 15 (August 2013), 219-241.

56. On the 2010-2011 electoral crisis in Côte d'Ivoire, see Giulia Piccolino, "David versus Goliath in Côte d'Ivoire: Laurent Gbagbo's war against global governance,” African Affairs, 111 (January 2012), 1-23; Thomas Bassett and Scott Straus, "Defending Democracy in Côte d'Ivoire: Africa Takes a Stand," Foreign Affairs, 90 (July/August 2011), 130-140.

57. The sous-préfectures visited include: Ando-Kékrénou, Bazra-Nattis, Béoumi, Blapleu, Bobi-Diarabana, Botro, Bouaké, Bouandougou, Bouna, Dabakala, Diabo, Djébonoua, Doropo, Foumbolo, Fronan, Gbangbégouiné-Y, Kamalo, Kani, Katiola, Korhogo, Kpata, Krofoinsou, Mahapleu, Man, Mankono, Marabadiassa, Podiagouiné, Sakassou, Sangouiné, Séguéla, Séitifla, Timbé, and Vavoua. We conducted additional interviews in Abidjan.

58. The questionnaire is available from the author's website: https://www.philipandrewmartin.com/ongoing-research 
59. The interview sample included both men and women, youth (18-35) and elderly persons, and active and retired military and government officials. Interviews were conducted in French, with translation to local languages occasionally provided by an interpreter.

60. Focus group, Kpata, August 52017.

61. Ibid.

62. Interview with village chief and notables, Kpata, August 52017.

63. Ibid.

64. Interview with village chief, Séguéla, July 272017.

65. Interview with civil society organization, Bobi, August 12017.

66. Interview with local administrator, Séguéla, 2 August 2017.

67. Interview with demobilized combatant, Séguéla, 4 August 2017.

68. Interview with deputy mayor, Séguéla, August 52017.

69. Interview with Mamadou Bakayoko, former delegate general of the FN in Séguéla and MP, 28 July 2017.

70. Gearóid Ó Loingsigh, Catatumbo: Un reto por la verdad, 2nd. edition (Bogota: Cisca, 2018), 49.

71. Wilfredo Cañizares Arévalo, "Catatumbo: la tragedia continúa”, Revista Arcanos 11 (2005), 37; See also Zukerman Daly, pp. 172-177.

72. Ó Loingsigh, p. 61.

73. Ibid., p. 66 .

74. Zukerman Daly, p. 179.

75. Vetcho comes from a family that was always politically active in Katiola. His mother, Virginie Aya Touré, has been president of the women's wing of the RDR and has been elected in Parliament in 2016.

76. Katiola was previously governed by a Malian military officer, nicknamed "Siriki."

77. Interview with traditional chief, Katiola, 26 July 2017.

78. Ibid.

79. Interview with civil society leader, Katiola, 27 July 2017.

80. Interview with deputy mayor, Katiola, 26 July 2017.

81. Philip A. Martin, "Security sector reform and civil-military relations in postwar Côte d'Ivoire," African Affairs, 117 (July 2018), 522-523. 
82. Interview with local journalist, Korhogo, 15 October, 2017.

83. Christine Cheng, Extralegal Groups in Post-Conflict Liberia. How Trade Makes the State (Oxford: Oxford University Press, 2018), p. 171.

84. Cheng, p. 179.

85. Interview with traditional chief, Béoumi department, Gbeké, 20 July 2017; Interview with civil society activist, Béoumi department, Gbeké, 20 July 2017; Interview with local government official and traditional leaders,

Djébonoua, Bouaké department, 25 July 2017.

86. Interview with traditional chief, Béoumi department, Gbeké, 20 July 2017; Interview with civil society activist, Béoumi department, Gbeké, 20 July 2017.

87. Interview with village chief, Béoumi, 20 July 2017; Interview with retired teacher, Sakassou, 25 July 2017;

Interview with local administrators, Djébonoua, 25 July 2017.

88. Interview with president of women's association, Botro, 24 July 2017.

89. Jeremy Speight, "Warlord undone? Strongman politics and post-conflict state-building in Northeastern Côte d'Ivoire," Canadian Journal of African Studies 48:2 (2014), 223-241.

90. See Alan Martin and Hélène Helbig de Balzac, "The West African El Dorado: Mapping the Illicit Trade of Gold in Côte d’Ivoire, Mali and Burkina Faso,” Partnership Africa-Canada (January 2017), 1-22.

91. Baudelaire Mieu, "Côte d'Ivoire : 22 morts lors d'affrontements intercommunautaires dans le Nord-Est." Jeune Afrique (25 March 2016) ; Morgane Le Cam, “Au Burkina Faso, avec les déplacés du conflit entre Peul et Lobi,” Le Monde (5 April 2016).

92. Interview with NGO worker, Doropo, Bounkani region, 8 August 2017; Interview with local politician, Bouna, Bounkani region, 3 August 2017.

93. Dipali Mukhopadhyay, Warlords, Strongman Governors, and the State in Afghanistan (Cambridge and New York: Cambridge University Press, 2014), p. 167.

94. Ibid.

95. Martin, Piccolino and Speight, p. 5.

96. Interview with deputy mayor, Korhogo, 15 October, 2017.

97. The family name Soro is extremely common in Northern Côte d'Ivoire. Kanigui and Alphonse are not related to each other, nor to the FN leader Guillaume Soro. 
98. Interview with Kanigui Soro, MP, 15 July 2017, Abidjan.

99. André Silver Konan, “Côte d'Ivoire: l'assassinat d'un pro-Soro à Korhogo ravive les tensions entre ex-rebelles et militants RDR,” Jeune Afrique (10 July 2018).

100. Interview with Kanigui Soro, MP, 15 July 2017, Abidjan.

101. Lyons; Kai Thaler, "When the Rebels Win: State Power and Public Interests after Civil War" (Ph.D. Diss., Department of Political Science, Harvard University 2018).

102. Reno, 2011.

103. David Lan, Guns and Rain. Guerrillas and Spirit Mediums in Zimbabwe (Berkeley, California, University of California Press, 1985), p. 210.

104. Jocelyn Alexander, "Things Fall Apart, The Centre Can Hold: Processes of Post-War Political Change in Zimbabwe's Rural Areas," in Ngwabi Bhebe and Terence Ranger, eds., Society in Zimbabwe's Liberation War (Harare: University of Zimbabwe, 1996).

105 Norma J. Kriger, Zimbabwe's Guerrilla War: Peasant Voices (Cambridge: Cambridge University Press, 1992), p. 214.

106. Kriger, p. 215.

107. Distinctions between "rebels" and "militias" often become blurred during armed conflicts, as each type of group engages in collaboration and conflict with the state. See Staniland, 2012, and Staniland, "Militias, Ideology and the State," Journal of Conflict Resolution 59 (2015), 770-793.

108. Kalyvas; Staniland, Networks of Rebellion: Explaining Insurgent Cohesion and Collapse (Ithaca: Cornell University Press, 2014).

109. Lt. Colonel Losseni Fofana ("Loss"), for example, the former FN zone commander in Man, remains highly respected and influential to this day.

110. For an analysis of state strategies vis-a-vis armed actors that emphasizes regime ideology, see Staniland, 2015.

111. For a similar argument see Marten, pp. 29-30.

112. Lyons.

113. Blair and Kalmanovitz.

114. Malejacq, p. 91.

115. Martin. 
116. Marten, pp. 29-30. 